\title{
SUMMARY LIST
}

\section{Nutritional Management of Cow Fertility}

225 Pre-and post-partum nutritional management to optimise fertility in high-yielding dairy cows in confined TMR systems

J K Drackley and F C Cardoso

226 Pre-and post-partum nutritional management to optimise fertility of dairy cows in pasture-based systems S T Butler

227 Optimising reproductive performance of beef cows and replacement heifers M G Diskin and D A Kenny

\section{Post Partum Cow Management and Health}

228 Parturition to resumption of ovarian cyclicity: comparative aspects of beef and dairy cows M A Crowe, M G Diskin, E J Williams

229 Reproductive tract inflammatory disease in postpartum dairy cows S J LeBlanc

\section{Pregancy Establishment}

230 Maternal-embryo interaction leading up to the peri-implantation period of pregnancy in cattle P Lonergan, N Forde

231 Physiological and practical effects of progesterone on reproduction in dairy cattle M C Wiltbank, A H Souza, P D Carvalho, A P Cunha, J O Giordano, P M Fricke, G M Baez, M G Diskin

232 Endocrine and metabolic mechanisms linking postpartum glucose with early embryonic and foetal development in dairy cows

M C Lucy, S T Butler, H A Garverick

\section{Genetics of Fertility}

233 Heifer fertility and carry over consequences for life time production in dairy and beef cattle D C Wathes, G E Pollott, K F Johnson, H Richardson, J S Cooke

234 Genetics and genomics of reproductive performance in dairy and beef cattle D P Berry, E Wall, J E Pryce

235 Crossbreeding - Implications for dairy cow fertility F Buckley, N Lopez-Villalobos, B J Heins

\section{Heat Detection and Oestrus/Ovulation Synchronisation}

237 Expression and detection of oestrus in dairy cows: The role of new technologies P M Fricke, P D Carvalho, J O Giordano, A Valenza, G Lopes Jr, M C Amundson

238 Synchronization of ovulation and fixed-time artificial insemination in beef cattle G A Bo, P S Baruselli

239 Synchronization of ovulation for management of reproduction in dairy cows R S Bisinotto, J E P Santos 


\section{Sexed Semen Technology and its Application}

$240 \quad$ Update on sexed semen technology in cattle

G E Seidel Jr

241 Applications and cost benefits of sexed semen in pasture-based dairy production systems S T Butler, I A Hutchinson

242 Improving bovine semen diluents: insights from the male and female reproductive tracts J A McGetrick, C J Reid, S D Carrington

\section{Herd Records and Management}

243 Herd monitoring to optimise fertility in the dairy cow - making the most of herd records, metabolic profiling and ultrasonography (research into practice)

R F Smith, J Oultram, H Dobson

244 Use of herd management programmes to improve reproductive performance of dairy cattle S McDougall, C Heuer, J Moreton, T Brownlie

\section{The Conference in Perspective}

245 Economics of fertility in high-yielding dairy cows on confined TMR systems V E Cabrera

246 Effect of fertility on the economics of pasture-based dairy systems L Shalloo, A Cromie, N McHugh

\section{SUBMITTED ORAL PRESENTATIONS}

$247 \quad \beta$-carotene supplementation to non-lactating dairy cows can restore $\beta$-carotene availability in the follicular environment under negative energy balance conditions

J De Bie, A Langbeen, A Verlaet, F Florizoone, I Immig, N Hermans, P E J Bols, J L M R Leroy

248 Live cell imaging in the female genital tract - new aspects for improving cow fertility

S Koelle, R Leeb, M Trottmann

249 Correlation study between reproduction and milk production traits in Holstein bulls with genetic evaluation available in Brazil D C Cucco, A Capelesso, J T Calgaro, E Ticiani, L G Gaya, M P Soares

250 Differential Immunoglobulin G glycosylation in postpartum dairy cows with uterine disease: potential for a predictive test E J Williams, H Stoeckmann, L Hobbs, B Adamcszyk, A C O Evans, P Rudd, S D Carrington

251 Optimal insemination time, oestrous characteristics and factors influencing conception rate on Dutch dairy farms equipped with pedometers

J Roelofs, K Huijps

252 Phenotypic and genotypic associations between multiple ovulations and milk production, longevity, fertility, and somatic cell count in Irish dairy cows

A Fitzgerald, D P Berry, R Evans, D Ryan

253 Incidence of clinical and subclinical endometritis in pasture managed dairy cows in Argentina and their effects on pregnancy rate at 100 days post partum

P M Chesta, Y Bonomini, F Mansutti, G Curchod, A Larriestra, G A Bó 

oestrous cycle

S G Moore, M McCabe, P Cormican, T Fair, P Lonergan, A J Chamberlain, J E Pryce, S T Butler

255 The in vitro assessment of sex-sorted fresh and frozen bull sperm

S A Holden, C Murphy, J F Moreno, A R Cromie, S T Butler, P Lonergan, S Fair

\section{SUBMITTED POSTER PRESENTATIONS}

256 Genome-wide association study of fertility traits in dairy cows

J Wu, J Zhang, M Teng, L Yang, J Yi, G Ha, J S Cooke, A M Clempson, G E Pollot, D C Wathes, S Zhang

257 Importance of reproductive traits on the moment of semen acquisition for dairy cattle by public agencies in Western Santa Catarina State - Brazil

V Broch, D C Cucco, J T Calgaro, R Ferreira, C Meotti, R Moura

258 Correlation study between reproduction and conformation traits in Holstein bulls with genetic evaluation available in Brazil

D C Cucco, A Capelesso, E Ticiani, J T Calgaro, L G Gaya, M P Soares

259 A comparison of the concentrations of pro-inflammatory cytokines in the uterine flush of dairy cows with or without endometritis

I H Kim, H G Kang, J K Jeong, T Y Hur, Y H Jung

260 Survey of genomic management practices of United States' dairy producers

J C Dalton, D Moore, T Spencer, H L Neibergs, A DeVries, P J Hansen, J B Cole

261 Effect of timing of artificial insemination and ovulation in relation to onset of standing heat on pregnancy rate in dairy buffaloes

N Ahmad, U Riaz, A Husnain, M Hassan, M I Naveed, A Sattar

262 Elevated non-esterified fatty acid concentrations during bovine oocyte maturation influences DNA methylation in blastocysts

K Desmet, V Van Hoeck, E Merckx, M.-A. Sirard, P E J Bols, J L M R Leroy

263 The effect of lameness on oestrus acvitity in high yielding Holstein-Friesian dairy cattle with access to pasture

A Ward, J Scaife, N Blackie

264 The effect of bovine placenta extract application on the postnatal complications, insemination efficiency and milk yield of the first lactation period Russian Black Pied cows

O S Mityashova, A A Goldina, G N Singina, N A Zinovieva

265 Comparison of two oestradiol esters administered with previously used CIDR for oestrous synchronization in buffalo cows during the low breeding season

A Sattar, M Ramzan, A Riaz, M-D Ahmad, A Haq, Nasim Ahmad

266 Trends and research in genetic aspects of fertility of dairy cattle in New Zealand N Dennis, P Amer, K Stachowicz, G Jenkins, S Meier

267 Failure to Imprint: Hypomethylation trends at imprinted loci in oocytes recovered from postpartum dairy cows

A M O’Doherty, A O’Gorman, A Al Naib, L Brennan, E Daly, P Duffy, T Fair

268 Associations between polymorphisms in five candidate genes, identified from transcriptional profiling of uterine endometrial tissue, in Holstein-Friesian bulls with either high or low genetic merit for calving interval M P Mullen, A P Killeen, D P Berry, C J Creevey, M G Diskin, D A Kenny, S M Waters 
Insulin during oocyte maturation alters gene expression and development rates in in vitro produced Day 8 bovine blastocysts

D Laskowski, Y Sjunnesson, M.-A Sirard, H Gustafsson, R Båge, G Andersson, P Humblot

270 Effect of lactation on the metabolic profile of dairy cattle

N Forde, L O’Hara, A Kelly, P Duffy, P Lonergan

271 Optimising the storage temperature and sperm concentration of liquid stored bull sperm C Murphy, S A Holden, S Fair

272 Effect of equine chorionic gonadotrophin administration on corpus luteum development, circulating progesterone concentrations and embryo developmnet in cattle

L O’Hara, N Forde, P Duffy, F Randi, A Kelly, P Rodriguez, P Lonergan

273 The use of a cowside lateral flow milk progesterone pest to aid reproductive management in a dairy herd P Ball, R Rogerson, G Maconochie, A Peters, M Hollingshead, M Fisher

Breeding soundness evaluation of 40 bulls with reduced reproductive performance: a retrospective study M Beltman, M Canty

275 Effect of physiological / disease status on the response of post partum dairy cows to synchronisation of oestrus using a CIDR device

J Mc Nally, M Crowe, M Beltman

276 Genetic associations between detailed reproductive traits and milk production in dairy cows T R Carthy, D P Berry, E J Williams, R D Evan, D P Ryan

277 Superovulation rates and embryo yields for heritage breed cattle and commercial dairy cattle K Lindell, D Roof, S Bowley

278 Expression of IL-1ß and its receptor IL R tI in bovine endometrium and embryos during early development E Correia-Alvarez, E Gomez, N Caamaño, C Diez, D Martin, S Carrocera, M Muñoz

279 Age-dependant adaptive capacity of bull sires during prolonged heat stress.

A Abilov, H Amerkhanov, G Eskin, N Kombarova, N Zhavoronkova, I Turbina, E Fedorova, S Guskova

280 Reproductive performance on four Irish grass based dairy herds: associations with milk production and milk composition

C Lynch, D A Kenny, M G Diskin 